\title{
Variation in Growth and Recruitment of Atlantic Cod (Gadus morhua) off Greenland During the Second Half of the Twentieth Century
}

\author{
Hans-Joachim Rätz and Manfred Stein \\ Institute for Sea Fisheries, Palmaille 9, D-22767 Hamburg \\ Federal Republic of Germany \\ and \\ Josep Lloret \\ Institut de Ciències del Mar - CSIC, Passeig Joan de Borbó s/n \\ E-08039 Barcelona, Spain
}

\begin{abstract}
The variation in length-at-ages 4 to 5 years for Atlantic cod (Gadus morhua) off Greenland was analysed based on a time series of samples taken from commercial catches comprising 190000 individual age determinations. Multiple linear regressions revealed significant declines in size for age groups 4 and 5 since the mid-1950s, by 10 and $5 \mathrm{~cm}$, respectively. Growth models accounting for temperature, fishing mortality and stock abundance effects were constructed. Positive temperature and negative fishing mortality effects were found to dominate the variation in length-at-age. The analyses did not indicate a negative effect of stock density on cod growth.

During the period 1956-89, the number of recruits at age 3 years was significantly correlated with the spawning stock biomass and June water temperature on top of Fyllas Bank (West Greenland). Both factors positively affected the number of offspring and explained $51 \%$ of the observed variation in recruitment.
\end{abstract}

Keywords: cod stock off Greenland, Gadus morhua, growth and recruitment variation

\section{Introduction}

Since the early-1920s, the marine life on the shelves and continental slopes off Greenland has been significantly affected by fishing activities. Until 1990, multi-national fleets directed their effort mainly on Atlantic cod (Gadus morhua), golden and deep sea redfish (Sebastes marinus and S. mentella). After the collapse of these offshore stocks, the shrimp (Pandalus borealis) and Greenland halibut (Reinhardtius hippoglossoides) fisheries remained the only ones of commercial importance.

The cod stock off Greenland was considered the main commercial and biological species of the area (Fig. 1), but collapsed at the end of the 1960s and has remained at a very low level since then (Anon., MS 1996). Cod abundance and spawning stock biomass have declined by almost $100 \%$ from the initial levels observed during the mid-1950s when annual catches exceeded 300000 tons for the first time. In addition to this major anthropogenic effect, studies on climatic and oceanographic conditions around Greenland (Buch and Stein, 1989) revealed concomitant interannual changes in the ocean and atmosphere which might have influenced fish biomass production in this area (Buch et al., 1994).

The main goal of the present investigation is to identify factors associated with the progressive commercial extinction of cod off Greenland. Constrained by the data available, we focussed our analyses on variation in length-at-age related to temperature, exploitation rates and fish density, and on recruitment variation related to temporal changes in spawning stock biomass and water temperature. We concluded that year to year variations of mean length-at-age and recruitment are affected by a combination of fishery, physical and biotic effects and have direct consequences for fish biomass production and management. However, the 


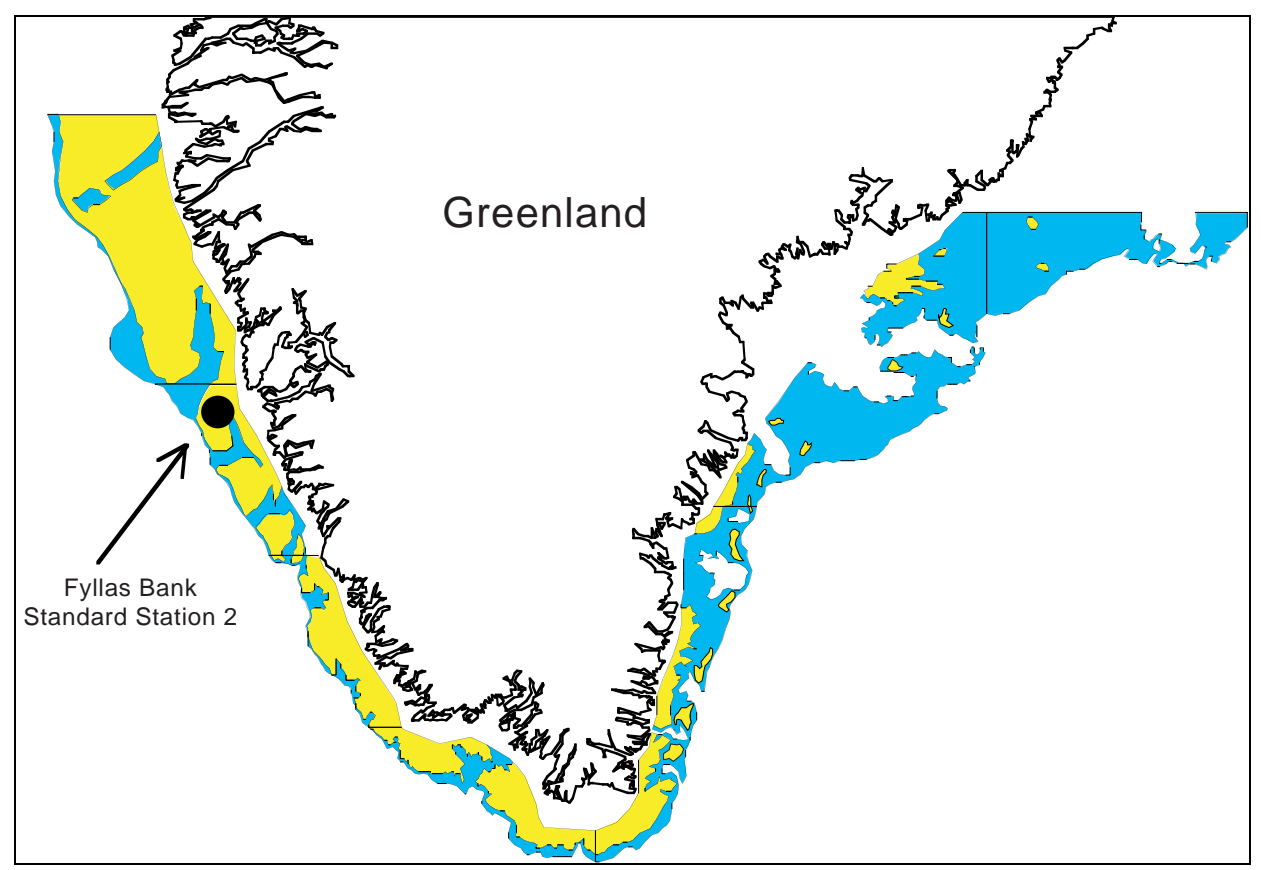

Fig. 1. Shelf and continental slope around Greenland (yellow $=50-200 \mathrm{~m}$ depth; blue $=$ 200-400 m depth), where the commercial cod fishery took place. The position of the oceanographic standard station on top of Fyllas Bank is indicated.

variation of these vital stock parameters seem to be inadequately incorporated in long-term harvest strategies.

\section{Materials and Methods}

\section{Interannual Variation in Length-at-Age}

Since 1955, length and age data were obtained from German commercial cod catches off East Greenland (ICES Div. XIVb) and West Greenland (NAFO Div. 1B-1F). Measurements and otolith collections were conducted directly on board the fishing vessels or derived from fresh fish landings at fish markets. Sampling strategy at fish markets was stratified by fish size categories, raised by the weight of each category, and added to represent the length composition of the landed catch by vessel. Length data measured on board the fishing vessels represented the sum of analysed catches. The sampling program comprised a total of 746 samples of length measurements and 190505 individual age determinations. Length measurements were performed with a precision of one centimetre $(\mathrm{cm}$ below). One of both sagitta otoliths was removed from the fish and stored in paper envelopes for subsequent age determination. The individual otoliths were cut through the central region and aged under a binocular microscope using transmitted light (Meyer, 1965).

Length-at-age data do not only vary interannually but are also subject to quarterly and areal effects. Therefore, length and otolith samples were aggregated by quarter (1955-91) for East and West Greenland separately. Mean length-at-age was calculated by applying the age-length keys to the length composition of the catches for each quarter and both areas. Only mean length-at-age values based on 10 or more age determinations were considered sufficiently precise and used in the present investigations. To eliminate the quarterly effect and to compare with the time when temperature measurements were conducted (June), mean length-at-ages 4 to 11 years observed in the first, third, and fourth quarter were converted to expected values in the second quarter by means of adding or substracting quarterly growth increments as calculated from significant linear regressions. For each year, the converted and the observed mean length at ages 4 to 11 in the second quarter were averaged to represent single annual values during the period of investigation. Both data sets for East and West Greenland were combined to one matrix by the calculation of weighted means according to 
the proportion caught in numbers off East and West Greenland (Horsted, MS 1994).

To reduce the effect of errors in age determination, length-at-age data were smoothed by fitting Bertalanffy (1938) growth functions for the yearclasses 1955 to 1981 . The parameters of the functions are listed in Table 1. The good fit between observed and predicted length-at-age data is confirmed by the resulting high $r^{2}$ values. Missing data in Table 1 indicate a poor fit of the Bertalanffy growth function to the length-at-age measurements for few year-classes which were disregarded in the analyses. The length at ages 4 and 5 as derived from the Bertalanffy growth funtcions are also listed in Table 1.

The interannual variation of the length at ages 4 and 5 years of the year-classes 1955 to 1981 was finally analysed by fitting univariate and multiple linear regression models based on temperature, stock size, and fishing mortality effects, all of them expressed as mean values over the life span of individual year-classes, respectively. Stock size estimates for ages 3 years and older and coefficients of fishing mortality rates were adopted from the most recent analytical assessment (Anon., MS 1996; Rätz, 1997).

\section{Interannual Variation in Recruitment}

Estimates of spawning stock biomass (SSB) and recruits at age 3 years were adopted from the virtual population analysis (VPA) conducted by the ICES North-Western Working Group in 1996 (Anon., MS 1996; Rätz, 1997). The VPA was based on international offshore catches only and calibrated by the German age disaggregated survey data (Rätz, MS 1996). Historic data revealed that cod off

TABLE 1. Parameters of the Bertalanffy growth functions $\left(t_{\mathrm{o}}, L_{\mathrm{inf}}, k\right)$ for year-classes $1955-81, r^{2}$ between observed and predicted mean length at ages 4-11, water temperature, stock abundance for ages $3+$ and mean fishing mortality $F$ at ages 5-8 (Anon., MS 1996).

\begin{tabular}{|c|c|c|c|c|c|c|c|c|c|}
\hline $\begin{array}{l}\text { Year-clas } \\
\text { Year }\end{array}$ & $t_{\mathrm{o}}$ & $\begin{array}{c}L_{\mathrm{inf}} \\
(\mathrm{cm})\end{array}$ & $k$ & $\begin{array}{c}r^{2} \\
\text { Lobs-Lcalc. }\end{array}$ & $\begin{array}{l}\text { Length }(\mathrm{cm}) \text { at } \\
\text { age } 4 \text { calculated }\end{array}$ & $\begin{array}{l}\text { Length }(\mathrm{cm}) \text { at } \\
\text { age } 5 \text { calculated }\end{array}$ & $\begin{array}{c}\text { Temp. } \\
\left({ }^{\circ} \mathrm{C}\right)\end{array}$ & $\begin{array}{c}\text { Stock 3+ } \\
\text { (millions) }\end{array}$ & Fmean 5-8 \\
\hline 1955 & -3.101 & 162.9 & 0.062 & 0.913 & 60.8 & 67.0 & 1.2 & 1341.1 & 0.109 \\
\hline 1956 & & & & & & & 0.9 & 1427.3 & 0.149 \\
\hline 1957 & 0.060 & 100.9 & 0.176 & 0.993 & 53.9 & 61.5 & 2.3 & 1115.6 & 0.210 \\
\hline 1958 & -1.143 & 115.2 & 0.115 & 0.991 & 54.3 & 60.9 & 2.2 & 994.1 & 0.202 \\
\hline 1959 & -2.877 & 154.3 & 0.060 & 0.994 & 54.5 & 60.3 & 1.6 & 1087.2 & 0.189 \\
\hline 1960 & -0.105 & 104.3 & 0.151 & 0.996 & 51.5 & 58.9 & 2.7 & 1332.2 & 0.194 \\
\hline 1961 & -0.460 & 104.5 & 0.142 & 0.999 & 52.1 & 59.0 & 3.2 & 1224.7 & 0.257 \\
\hline 1962 & -0.864 & 111.0 & 0.115 & 0.989 & 50.5 & 57.1 & 2.2 & 956.2 & 0.404 \\
\hline 1963 & & & & & & & 1.6 & 1016.6 & 0.369 \\
\hline 1964 & -0.050 & 115.1 & 0.117 & 0.879 & 46.8 & 54.4 & 2.3 & 1385.6 & 0.387 \\
\hline 1965 & & & & & & & 2.1 & 1301.3 & 0.411 \\
\hline 1966 & 2.357 & 106.7 & 0.216 & 0.913 & 38.1 & 51.4 & 1.6 & 1240.3 & 0.402 \\
\hline 1967 & -0.639 & 225.5 & 0.048 & 0.980 & 48.2 & 56.4 & 1.5 & 954.2 & 0.414 \\
\hline 1968 & 0.657 & 151.2 & 0.101 & 0.995 & 47.6 & 57.6 & 2.1 & 643.7 & 0.440 \\
\hline 1969 & 2.603 & 99.0 & 0.313 & 0.981 & 42.6 & 57.8 & 0.3 & 406.0 & 0.379 \\
\hline 1970 & & & & & & & 0.3 & 264.1 & 0.219 \\
\hline 1971 & 2.086 & 110.1 & 0.249 & 0.950 & 48.3 & 61.9 & 0.8 & 251.2 & 0.398 \\
\hline 1972 & 1.152 & 126.8 & 0.144 & 0.981 & 47.4 & 58.1 & 0.6 & 160.6 & 0.473 \\
\hline 1973 & 1.055 & 99.4 & 0.202 & 0.992 & 48.8 & 58.0 & 1.7 & 101.9 & 0.431 \\
\hline 1974 & 1.043 & 102.2 & 0.161 & 0.961 & 42.7 & 51.6 & 1.4 & 53.3 & 0.670 \\
\hline 1975 & 0.655 & 100.7 & 0.153 & 0.934 & 43.9 & 52.0 & 1.9 & 50.7 & 0.906 \\
\hline 1976 & 2.591 & 87.3 & 0.340 & 0.993 & 40.1 & 53.7 & 1.4 & 181.7 & 0.821 \\
\hline 1977 & -0.069 & 136.3 & 0.094 & 0.989 & 46.9 & 55.0 & 2.2 & 140.1 & 0.764 \\
\hline 1978 & & & & & & & 0.9 & 112.9 & 0.267 \\
\hline 1979 & 1.040 & 139.3 & 0.112 & 0.928 & 43.6 & 53.7 & 2.3 & 100.5 & 0.294 \\
\hline 1980 & 2.894 & 97.5 & 0.268 & 0.851 & 32.3 & 47.6 & 1.9 & 143.4 & 0.502 \\
\hline 1981 & 1.159 & 122.7 & 0.134 & 0.887 & 43.3 & 53.3 & 1.6 & 107.8 & 0.414 \\
\hline 1982 & & & & & & & 0.8 & 127.2 & 0.751 \\
\hline 1983 & & & & & & & 0.4 & 82.3 & 0.913 \\
\hline 1984 & & & & & & & 1.0 & 54.9 & 0.686 \\
\hline 1985 & & & & & & & 2.1 & 32.4 & 0.241 \\
\hline 1986 & & & & & & & 2.2 & 33.0 & 0.159 \\
\hline
\end{tabular}


Greenland mature at ages 5 to 7 . VPA results demonstrated the quick and continuous decrease in spawning stock biomass (SSB) by more than 90\% from 1955 until the early-1970s while fishing mortality rates increased to $0.4-0.6$. Thereafter, the stock remained at that low level whereas fishing mortality varied over a wide range due to intensive exploitation of the strong 1973 and 1984 yearclasses. Recruitment was highly variable and exceeded the average level every second year when spawning stock biomass exceeded 1 million tons. Apart from the strong 1973 and 1984 year-classes (>150 million at age 3 ), recruitment was very poor after the stock collapse. Numbers of recruits at age
3 years were taken as an estimate of year-class strength at age 0 in order to compare with the conditions in the particular years of birth. We used multiple linear regression to formulate a recruitment model based on SSB and temperature effects. The data used in this analyses are listed in Table 2.

\section{Water Temperature}

Water temperatures on the top of Fyllas Bank off West Greenland (Stein, MS 1988) were sampled by the Greenland Fisheries Research Institute, Copenhagen during mid-June of each year since 1950 (Fig. 1). The mean temperature of the surface layer was derived by averaging the observations at

TABLE 2. Estimates of spawning stock biomass (SSB), water temperature, and recruits at age 3 years (Anon., MS 1996), 1955-89.

\begin{tabular}{|c|c|c|c|}
\hline Year-class/Year & SSB (1 000 tons $)$ & Temperature $\left({ }^{\circ} \mathrm{C}\right)$ & Recruits at Age 3 (millions) \\
\hline 1955 & 1817.5 & 1.2 & 134.5 \\
\hline 1956 & 1519.5 & 0.9 & 463.7 \\
\hline 1957 & 1331.3 & 2.3 & 531.7 \\
\hline 1958 & 1469.3 & 2.2 & 226.9 \\
\hline 1959 & 1042.4 & 1.6 & 93.6 \\
\hline 1960 & 1228.8 & 2.7 & 409.6 \\
\hline 1961 & 1083.5 & 3.2 & 703.4 \\
\hline 1962 & 1035.9 & 2.2 & 286.7 \\
\hline 1963 & 1020.4 & 1.6 & 330.0 \\
\hline 1964 & 887.2 & 2.3 & 105.6 \\
\hline 1965 & 716.2 & 2.1 & 37.5 \\
\hline 1966 & 715.5 & 1.6 & 39.1 \\
\hline 1967 & 828.7 & 1.5 & 22.8 \\
\hline 1968 & 775.9 & 2.1 & 88.0 \\
\hline 1969 & 572.0 & 0.3 & 4.2 \\
\hline 1970 & 467.0 & 0.3 & 9.2 \\
\hline 1971 & 378.3 & 0.8 & 6.2 \\
\hline 1972 & 248.1 & 0.6 & 24.6 \\
\hline 1973 & 109.5 & 1.7 & 154.6 \\
\hline 1974 & 88.9 & 1.4 & 16.6 \\
\hline 1975 & 54.8 & 1.9 & 20.1 \\
\hline 1976 & 30.1 & 1.4 & 26.8 \\
\hline 1977 & 20.6 & 2.2 & 71.1 \\
\hline 1978 & 37.8 & 0.9 & 14.3 \\
\hline 1979 & 78.8 & 2.3 & 56.5 \\
\hline 1980 & 94.1 & 1.9 & 7.7 \\
\hline 1981 & 71.1 & 1.6 & 13.8 \\
\hline 1982 & 57.2 & 0.8 & 2.0 \\
\hline 1983 & 46.6 & 0.4 & 10.9 \\
\hline 1984 & 35.6 & 1.0 & 265.7 \\
\hline 1985 & 29.9 & 2.1 & 85.1 \\
\hline 1986 & 32.9 & 2.2 & 1.4 \\
\hline 1987 & 36.2 & 2.1 & 1.6 \\
\hline 1988 & 56.4 & 2.0 & 0.6 \\
\hline 1989 & 83.6 & 0.9 & 0.3 \\
\hline
\end{tabular}


the standard levels, $0,10,20,30$ and $40 \mathrm{~m}$. Buch (1984) showed that the temperature trends in neighbouring areas and periods were similar to those on Fylla Bank due to the process of advection and solar heating. Therefore, the mid-June temperature regime on Fylla Bank is considered to be representative index of the thermal conditions in the shelf region off West Greenland (Hansen and Buch, 1986).

\section{Results}

\section{Interannual Variation in Length-at-Age}

The various year-classes displayed a high variation in growth. The estimates of $L_{\text {infinity }}$ ranged from 87 to $226 \mathrm{~cm}$ (Table 1). The coefficients $k$ representing the growth rates of the individual yearclasses were rather small and varied between 0.06 and 0.34 . The time series of mean length-at-ages 4 and 5 showed an overall decreasing trend with high variations since the stock collapsed at the end of the 1960s (Fig. 5a and 5b). Mean length-at-ages 4 and 5 declined from 61 and $67 \mathrm{~cm}$ in 1959 and 1960 to 43 and $53 \mathrm{~cm}$ in 1985 and 1986, respectively.

Mean length at ages 4 and 5 were found to be correlated with temperature. Fish sizes increased significantly with increasing water temperature on top of Fyllas Bank (Fig. 2). Temperature explained 33 and $15 \%$ of the observed variation in mean length-at-ages 4 and 5, respectively. Strong negative correlations between observed fish sizes and mean fishing mortality were found. Fish were signifi-

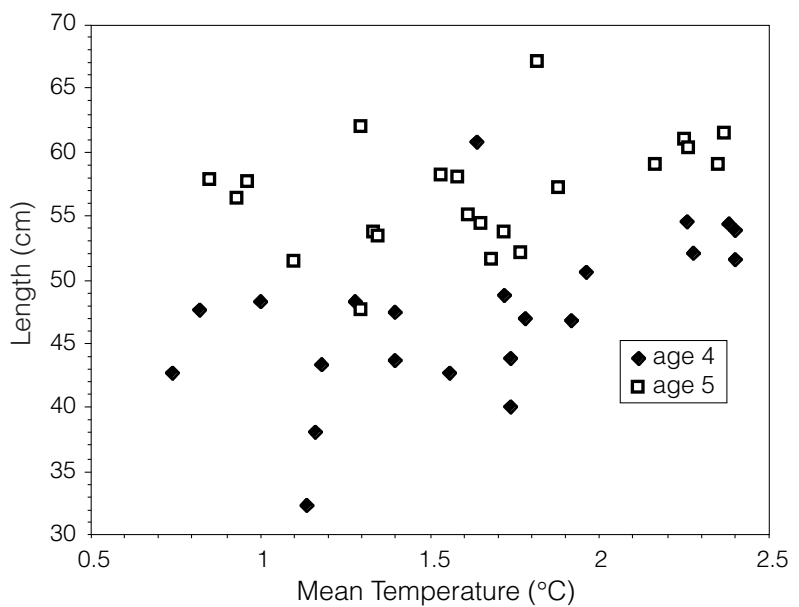

Fig. 2. Scatter plot of mean June water temperature over life span of the individual year-classes versus their mean length-at-ages 4 and 5 $\left(r_{\text {age } 4}^{2}=0.33 ; r_{\text {age } 5}^{2}=0.15\right)$. cantly smaller in years with high exploitation rates. Mean fishing mortality explained 42 and $32 \%$ of the observed variation in age groups 4 and 5, respectively (Fig. 3). The strongest correlations were found between fish size at age and stock abundance of age groups 3 and older. Age 4 and 5 year old cod were big when the stock abundance was high (Fig. 4). The positive density effect accounted for 46 and $33 \%$ of the observed variation in length.

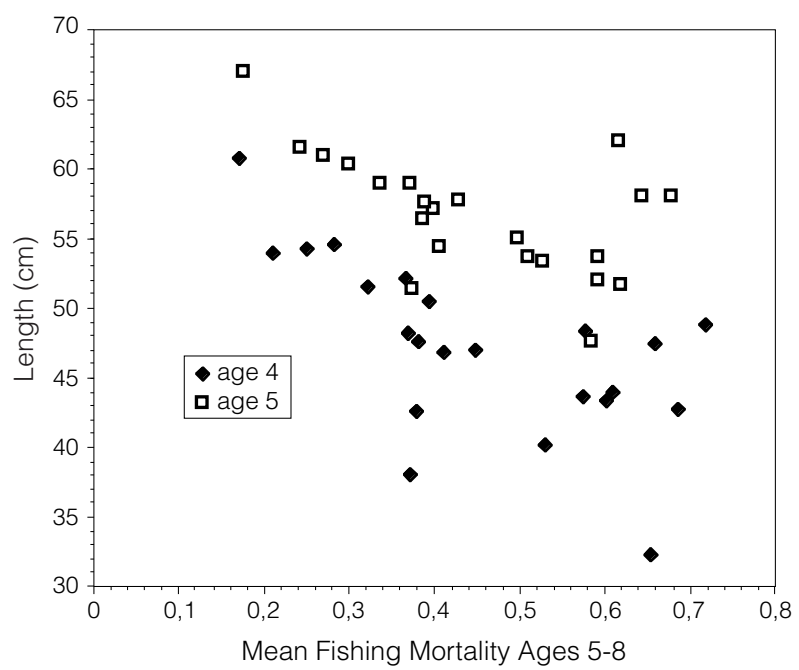

Fig. 3. Scatter plot of mean fishing mortality ages at ages 5-8 over the life span of the individual year-classes versus their mean length-at-ages 4 and $5\left(r_{\text {age } 4}^{2}=0.42 ; r_{\text {age } 5}^{2}=0.32\right)$.

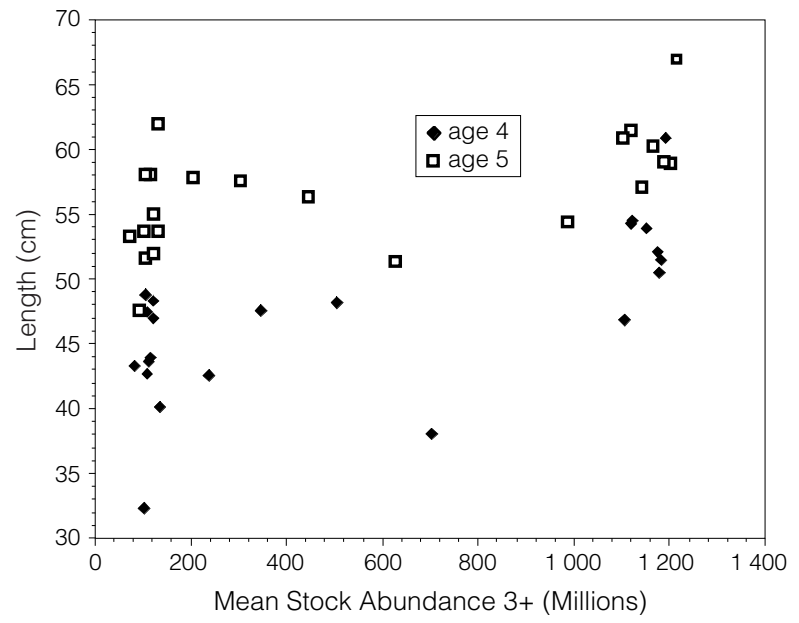

Fig. 4. Scatter plot of mean stock abundance $3+$ over the life span of the individual year-classes versus their mean length-at-ages 4 and $5\left(r^{2}\right.$ age 4 $\left.=0.46 ; r_{\text {age } 5}^{2}=0.33\right)$. 
The individual relationships between variations in mean length at ages 4 and 5 (dependent) and mean temperature over life span (independent), mean fishing mortality (independent) and mean stock size in number (independent) were combined in multiple linear regression models. The models explained 54 and $36 \%$ of the observed variation in mean fish size for ages 4 and 5, respectively. Both models are specified in Table 3 and illustrated in Fig. $5 \mathrm{a}$ and $5 \mathrm{~b}$.

\section{Interannual Variation in Recruitment}

From 1955 to 1989, the cod stock off Greenland has undergone important demographic changes. Both spawner biomass and recruitment declined by nearly $100 \%$ when comparing initial and final estimates (Table 2). The spawning stock biomass and number of recruits at age 3 collapsed from 1.8 million tons and 134 million to 250000 tons and 25 million respectively in 1972 . Since then, the estimates varied at this low level and continued to decline with the exception of the two strong yearclasses 1973 and 1984 which did not contribute to an increase in the spawning stock biomass (Fig. 8).

Figure 6 shows the scatter plot of estimates of recruits at age 3 versus the water temperature observed on top of Fyllas Bank. The resulting $r^{2}$ betweeen both variables amounted to 0.20 indicating a significant positive effect of temperature on the number of recruits. Also the spawning stock biomass was found to be significantly correlated with the recruitment $\left(r^{2}=0.41\right)$. The scatter plot in Fig. 7 illustrates that the estimated variation in spawning stock biomass has a higher explanatory weight for recruitment strength than the temperature variation.

We formulated a multiple linear regression model for the numbers of recruits at age 3 (dependent) based on the positive temperature (independent) and spawning stock biomass (independent) effects. This model is specified in Table 4 and explained $51 \%$ of the variation in yearclass strength at age 3 . For the period of investigation, the fit between observed and model predicted values is illustrated in Fig. 8.

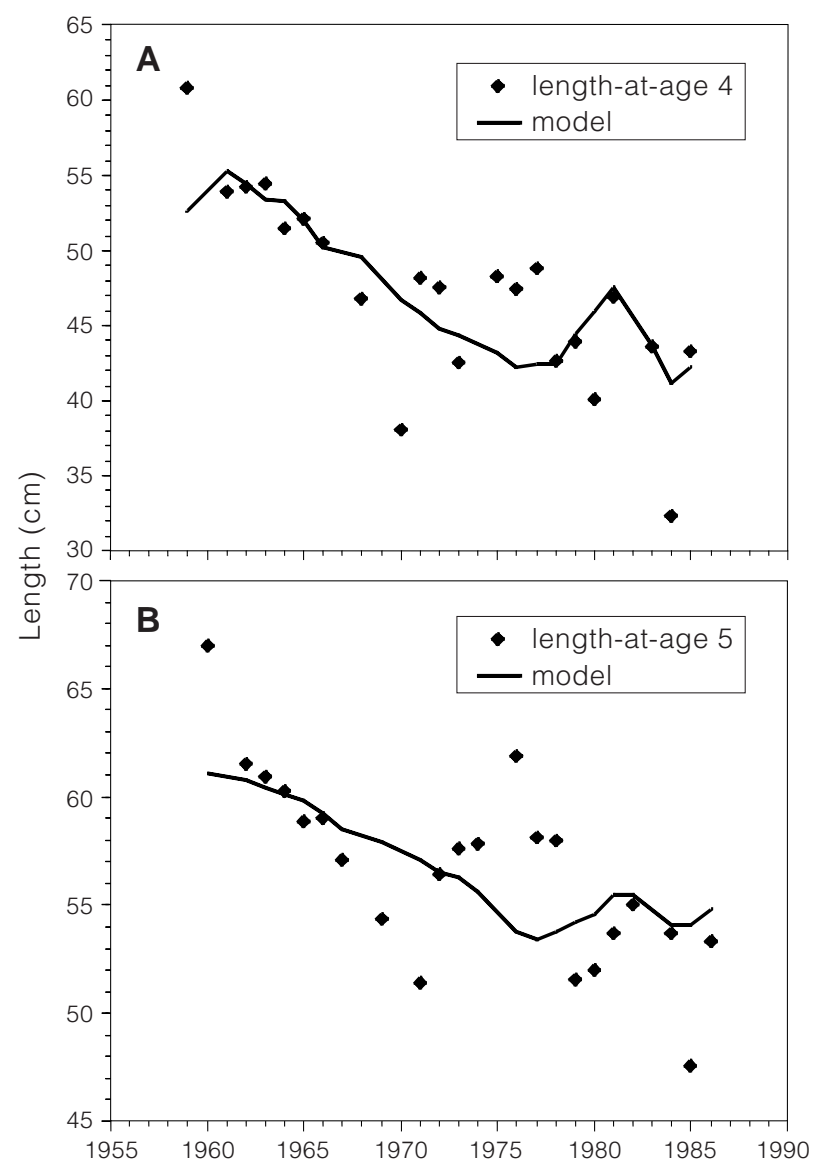

Fig. 5. (A) length-at-age 4 years as observed in commercial catches and derived from the multiple linear regression model (Table 3 ), 1959-85; (B) length-at-age 5 years as observed in commercial catches and derived from the multiple linear regression model (Table 3 ), 1960-86.

TABLE 3. Results of multiple linear regression analyses between length at ages 4 and 5 years (cm, dependent) and mean water temperature $\left({ }^{\circ} \mathrm{C}\right.$, independent), mean $\mathrm{F}$ ages $5-8$ (independent) and mean stock abundance (ages $3+$ in millions, independent) over life span. All parameters are significant at $p<0.01$.

\begin{tabular}{lcccccc}
\hline \hline $\begin{array}{c}\text { Length-at-age } \\
(\mathrm{cm})\end{array}$ & $n$ & $a$ & $\begin{array}{c}\text { Temperature } \\
\left({ }^{\circ} \mathrm{C}\right)\end{array}$ & $\begin{array}{c}F_{\text {mean }} \\
(5-8)\end{array}$ & $\begin{array}{c}\text { Stock 3+ } \\
(\text { millions })\end{array}$ & $r^{2}$ \\
\hline 4 years & 22 & 47.753 & 4.301 & -17.721 & 0.001 & 0.541 \\
5 years & 22 & 59.205 & 1.183 & -11.543 & 0.001 & 0.355 \\
\hline
\end{tabular}




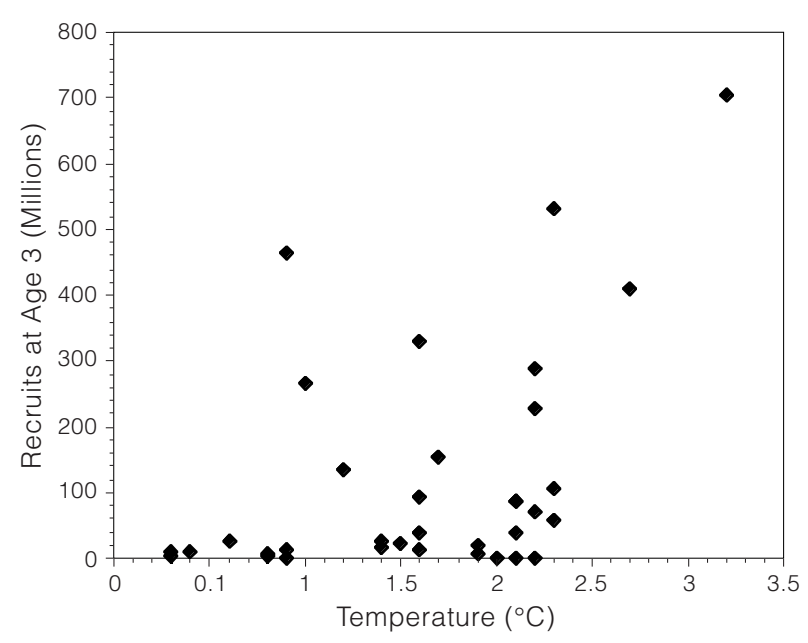

Fig. 6. Scatter plot of June water temperature versus recruits-at-age $3\left(r^{2}=0.20\right), 1955-89$.

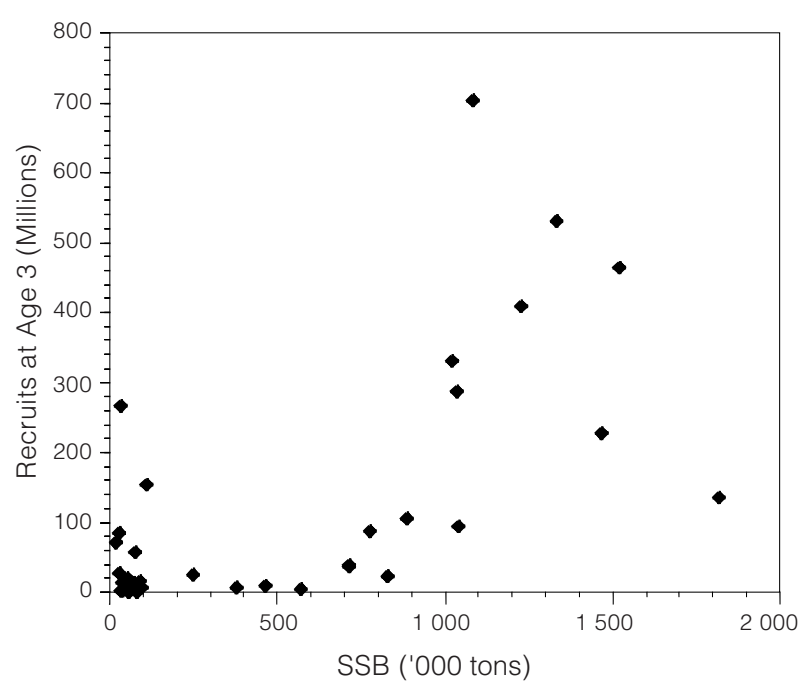

Fig. 7. Scatter plot of spawning stock biomass (SSB) versus recruits-at-age $3\left(r^{2}=0.41\right), 1955-89$.

\section{Discussion}

\section{Interannual Variation in Length-at-Age}

Our analyses revealed significant reductions in mean length of Atlantic cod off Greenland at ages 4 and 5 since the mid-1950s by 10 and $5 \mathrm{~cm}$, respectively. Similar declines in size-at-age have been documented for the cod stocks around the Faroe Islands (Jákupsstovu and Reinert, 1994) and off Labrador (Shelton and Morgan, 1994). We investigated the age groups 4 and 5 due to their major contribution to catch in number throughout the period of investigation. Since the late-1960s when the stock collapsed, size estimations of older fish were probably less representative due to their rarity in the catches. It should be noted that the raw data were derived from commercial catches and could not be corrected for small scale areal and depth effects which are considered to contribute significantly to the observed variation (Jørgensen, 1992). However, multiple linear regressions suggest that size at ages 4 and 5 years are positively affected by temperature and stock abundance while the fishing mortality was identified to have a negative effect (Table 3, Fig. 5a and 5b). Our analyses are based on arithmetic means of the temperature, stock abundance and fishing mortality over the life span of the cohorts in order to reflect their cumulative effects on growth rates. These models (multiple linear regression) are highly significant and explained 54 and $36 \%$ of the observed variation in length at ages 4 and 5.

For decades, the influence of environmental conditions on growth of cod has been a central question in fisheries biology and has attracted considerable scientific interest (Taylor, 1958). Most authors (e.g. Hansen, 1949; Dementyeva and

TABLE 4. Results of multiple regression between recruitment at age 3 (million, dependent) and water temperature $\left({ }^{\circ} \mathrm{C}\right.$, independent) and SSB (1 000 tons, independent). All parameters are significant at $p<0.01$.

\begin{tabular}{cccccr}
\hline \hline $\begin{array}{c}\text { Recruits at age } \\
\text { (millions) }\end{array}$ & $n$ & $a$ & $\begin{array}{c}\text { Temperature } \\
\left({ }^{\circ} \mathrm{C}\right)\end{array}$ & $\begin{array}{c}\text { SSB } \\
(1000 \mathrm{t})\end{array}$ & $r^{2}$ \\
\hline 3 & 35 & -99.485 & 78.240 & 0.185 & 0.508 \\
\hline
\end{tabular}




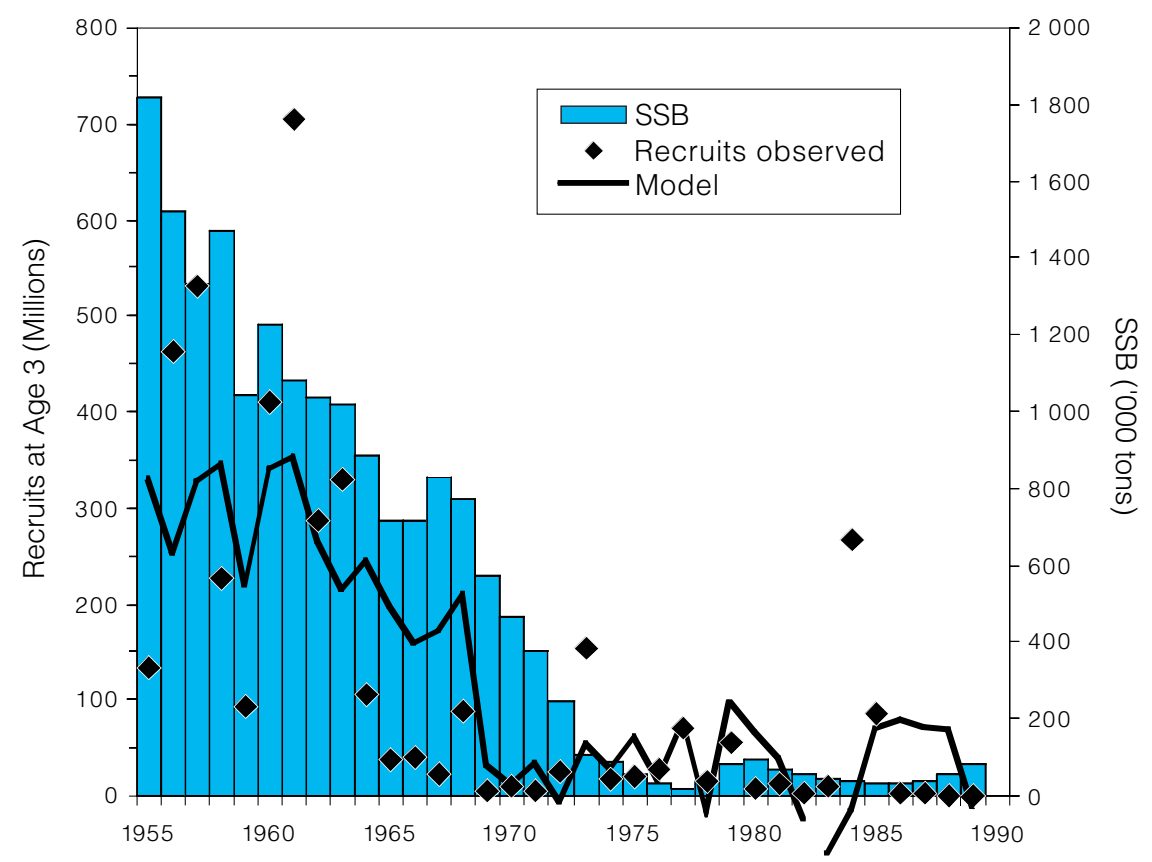

Fig. 8. Spawning stock biomass, recruitment variation and fit of the multiple linear regression model (Table 4), 1955-89.

Mankevich, 1965; Jónsson, 1965; Jørgensen, 1992; Nakken, 1994; Brander, 1995) have found positive regressions between temperature and fish size-atage which were also apparent from the analyses presented here. Brander (1995) concluded that yearto-year variation in weight-at-age of cod within and between stocks might be largely controlled by water temperature and highlighted the importance in respect of stock and catch assessments and resulting predictions used for management purposes. In addition to the direct effect of temperature on the growth physiology of poikilothermic animals (assimilation, metabolism, transformation, and excretion; Brett, 1979) there could also be indirect effects such as changes in food quality or availability. Jørgensen (1992), Nilssen et al. (1994), and Steinarsson and Stefanson (MS 1991) demonstrated positive effects of capelin (Mallotus villosus) abundance on the growth rates of ArctoNorwegian and Icelandic cod, the main food item of these stocks.

Fish density has been considered to be an important factor determing growth rates because of intra-specific competition. Theoretically, growth rates should decrease with increasing abundance (Hempel, 1957). The results of the present study do not support this. In the case of the North Sea cod there was also no evidence of density effects providing a likely explanation for variation in growth (Daan et al., 1994). In our study the absence of density-dependent growth is difficult to explain since pronounced inverse abundance effects were reported from the Northeast Arctic (Nilssen et al., 1994) and Icelandic stocks (Schopka, 1994).

During periods of intensive exploitation, as indicated by high fishing mortalities, the Atlantic cod off Greenland at age 4 and 5 were found to be very small. These results do not necessarily reflect changes in growth rates but may point to a higher selection of the fast growing individuals by the fishery. Exploitation rates which frequently exceeded $70 \%$ of the fishable stock (Anon., MS 1996) over the past 40 years support the idea of higher survival rates of slow growing individuals.

\section{Interannual Variation in Recruitment}

For more than 50 years, fisheries biologists focussed their interest in the role of the spawning stock biomass (SSB) and temperature as determinant factors of fish recruitment (Berverton and Holt, 1957; Cushing, 1982; Ricker, 1975). Size of the SSB is generally accepted as a very important indicator of the exploitation status of the majority of marine fish stocks (Anon., MS 1997; Serchuk et 
al., MS 1997). Our analyses identified both water temperature and SSB as important factors for the reproductive success of the cod stock off Greenland. The multiple linear regression model based on these two independent variables explains $51 \%$ of the observed variation in 3 year old offspring during 1955-89 and shows the dominant explanatory weight of SSB (Table 4, Fig. 8). Thus, our results provide strong evidence that the collapse of the cod stock off Greenland in the late-1960s was mainly due to the progressive extinction of the spawners by fishing activities (Rätz, 1997). In particular, the model indicates the importance of a high SSB at the northern limit of cod distribution to compensate for adverse environmental effects on recruitment success. Before the stock collapsed in the late1960 s, recruitment was highly variable and failed in some years even with high SSB, but there were only two strong year-classes produced during the past 30 years, namely the 1973 and 1984 yearclasses. The model fit increases significantly to $59 \%$ by omission of these strong year-classes. The yearclasses 1973 and 1984 are thought to be of Icelandic origin and to have drifted in the Irminger current to Greenland nursery grounds (Vilhjálmsson and Fridgeirsson, 1976; Vilhjálmsson and Magnússon, MS 1984).

The sudden decline of SSB was an important factor during the collapse of northern cod of Newfoundland and Labrador in the early-1990s (Hutchings and Myers, 1994). In addition, environmental parameters are considered to contribute significantly to cod recruitment success (Lear and Parsons, 1993; de Young and Rose, 1993). Evidence of biotic and physical influences on Northeast Arctic cod recruitment has been documented by Ottersen and Sundby (1995) and Nilssen et al. (1994). They identified positive effects of SSB and temperature on year-class strength of similar magnitude to those determined in the present analysis.

\section{Acknowledgement}

Josep Lloret was financially supported by a fellowship of the D. G. Research of the Government of Catalonia.

\section{References}

ANON. MS 1996. Report of the North-Western Working Group. ICES C.M. Doc., No. Assess: 15, 377 p. MS 1997. Report of the Study Group on the
Precautinary Approach to Fisheries Management. ICES C.M. Doc., No. Assess: 7, 31 p.

BEVERTON, R: J. H., and S. HOLT. 1957. On the dynamics of exploited fish populations. Fish. Invest., Ser., 2 (19), 533 p.

BERTALANFFY, VON. 1938. A Quantitative Theory of Organic Growth. Hum. Biol., 10(2): 181-213.

BRANDER, K. M. 1995. The effect of temperature on growth of Atlantic cod (Gadus morhua L.). ICES J. Mar. Sci., 52: 1-10.

BRETT, J. R. 1979. Environmental factors and growth. In: Fish physiology, W. S. Hoar, D. J. Randall, and R. J. Brett (eds.) Vol. III, Academic Press, New York/ San Fransisco/London, p. 599-675.

BUCH, E. 1984. Variations in temperature and salinity of West Greenland waters, 1970-82. NAFO Sci. Coun. Studies, 7: 39-44.

BUCH, E. and M. STEIN. 1989. Environmental Conditions off West Greenland, 1980-85. J. Northw. Atl. Fish. Sci., 9: 81-89.

BUCH, E., S. A. HORSTED, and H. HOVGÅRD. 1994. Fluctuations in the occurrence of cod in Greenland waters and their possible causes. ICES Mar. Sci. Symp., 198: 158-174.

CUSHING, D.H. 1982. Climate and Fisheries. Academic Press Inc. London, $373 \mathrm{p}$.

DAAN, N., H. J. L. HEESEN, and J. G. POPE. 1994. Changes in the North Sea cod stock during the twentieth century. ICES Mar. Sci. Symp., 198: 229243.

DeYOUNG, B., and G. A. ROSE. 1993. On recruitment and distribution of Atlantic cod (Gadus morhua) off Newfoundland. Can. J. Fish. Aquat. Sci., 50: 27292741.

DEMENTYEVA, T. F., and E. M. MANKEVICH. 1965. Changes in the growth rate of the Barents Sea cod as affected by environmental factors. ICNAF Spec. Publ., 6: 571-577.

HANSEN, P. M. 1949. Studies on the Biology of Cod in Greenland Waters. ICES Rapp. Proc.-Verb., 123: $1-77$.

HANSEN, H., and E. BUCH. 1986. Prediction of yearclass strength of Atlantic cod (Gadus morhua) off West Greenland. NAFO Sci. Coun. Studies, 10: 7-11.

HEMPEL, G. 1957. A short note on the relationship between stock density and growth. Joint ICES/ ICNAF/FAO Scientific meeting, 1957. ICNAF Spec. Publ., 2: 35.

HORSTED, SV. AA. MS 1994. A Review with Some Proposals for Amendments of the Catch Statistics for the Cod Fisheries in Greenland Waters Since 1911. NAFO SCR Doc., No. 38, Serial. No. N2407, $33 \mathrm{p}$.

HUTCHINGS, J. A., and R. A. MYERS. 1994. What can be learned from the collapse of a renewable resource? Atlantic cod (Gadus morhua), of Newfoundland and Labrador. Can. J. Fish. Aquat. Sci., 51: 2126-2146.

JÁKUPSSTOVU, S. H., and J. REINERT. 1994. 
Fluctuations in the Faroe Plateau cod stock. ICES Mar. Sci. Symp., 198: 194-211.

JÓNSSON, J. 1965. Temperature and growth of cod in Icelandic waters. ICNAF Spec. Publ. 6: 537-539.

JØRGENSEN, T. 1992. Long-term changes in growth of North-east Arctic cod (Gadus morhua) and some environmental influences. ICES J. Mar. Sci., 49: 263-277.

LEAR, W. H., and L. S. PARSONS. 1993. History and management of the fishery for northern cod in NAFO Div. 2J. 3K and 3L. In: Perspectives on Canadian marine fisheries management. L.S. Parsons and W.H. Lear (eds.). Can. Bull. Fish. Aquat. Sci., 226: 55-89.

MEYER, A. 1965. Sawing Otoliths as Mechnical Aid of Otolith Reading. ICNAF Res. Bull., 2: 78-79.

NILSSEN, E. M., T. PEDERSEN, C. C. E. HOPKINS, K. THYHOLT, and J. G. POPE. 1994. Recruitment variability and growth of Northeast Arctic cod: influence of physical environment, demography, and predator-prey energetics. ICES J. Mar. Sci., 198: 449-470.

NAKKEN, O. 1994. Causes of trends and fluctuations in the Arcto-Norwegian cod stock. ICES Mar. Sci. Symp., 198: 212-228.

OTTERSEN, G., and S. SUNDBY. 1995. Effects of temperature, wind and spawning stock biomass in recruitment of Arcto-Norwegian cod. Fish. Oceanogr., 4: 278-292.

RÄTZ, H.-J. MS 1996. Groundfish Survey Results 198295 and Length and Age Structure of German Landings 1952-93 for Cod off Greenland (offshore component). ICES North-Western-Working Group 1996, Working Paper 9: $32 \mathrm{p}$.

RÄTZ, H.-J. 1997. Die Entwicklung des atlantischen
Kabeljaubestandes vor Grönland in der zweiten Hälfte des 20. Jahrhunderts. Inf. Fischw., 44(1): 3-9.

RICKER, W. E. 1975. Computation and Interpretation of Biological Statistics of Fish Populations. Bull. Fish. Res. Bd. Can., 191: 382 p.

SCHOPKA, S. A. 1994. Fluctuations in the cod stock off Iceland during the twentieth century in relation to changes in the fisheries and environment. ICES Mar. Sci. Symp., 198: 175-193.

SERCHUK, F. M., D. RIVARD, J. CASEY, and R. MAYO. MS 1997. Report of the Ad hoc Working Group of the NAFO Scientific Council on the Precautionary Approach. NAFO SCS Doc., No. 12, Serial No. N2911, 61 p.

SHELTON, P. A., and M. J. MORGAN. 1994. An Analysis of Spawner Biomass and Recruitment of Cod (Gadus morhua) in Divisions $2 \mathrm{~J}$ and $3 \mathrm{KL}$. NAFO Sci. Coun. Studies, 21: 67-82.

STEIN, M. MS 1988. Revision of list of NAFO standard oceanographic sections and stations. NAFO SCR Doc., No. 1, Serial No. N1432, 9 p.

STEINARSSON, B. Æ., and G. STEFFANSON. MS 1991. An attempt to explain cod growth variability. ICES C.M. Doc., No. G:42, 21 p.

TAYLOR, C. C. 1958. Cod growth and temperature. ICES J. Cons., 23: 366-370.

VILHJÁLMSSON, H., and E. FRIDGEIRSSON. 1976. A review of 0-group surveys in the Iceland-East Greenland area in the years 1970-1975. ICES Coop. Res. Rep., 54: 1-34.

VILHJÁLMSSON, H., and J. V. MAGNÚSSON. MS 1984. Repoprt of the 0-Group Fish Survey in Icelandic and East Greenland Waters, August 1984. ICES C.M. Doc., No. H:66, 15 p. 